\title{
Institutional Ownership and Tax Avoidance: A Review Agency Theory
}

\author{
Pasca Dwi Putra ${ }^{1}$, Dedy Husrizal Syah ${ }^{2}$, Baginda Halim Simatupang ${ }^{3}$ \\ \{sgacenter@gmail.com ${ }^{1}$, dedy@unimed.in ${ }^{2}$ \} \\ Department of Business Education, Universitas Negeri Medan, Medan, Indonesia ${ }^{1}$ \\ Department of Accounting, Universitas Negeri Medan, Medan, Indonesia ${ }^{2,3}$
}

\begin{abstract}
Differences in interests between owners and managers cause information submitted to financial statements to be incorrect. The interests of owners who want increased company performance and value cause managers to plan strategies, one of which is tax avoidance. Therefore, this study aims to determine the conflict of interest between managers and owners who are described through institutional ownership of tax avoidance practices. This research was conducted on manufacturing companies listed on the Indonesia and Singapore Stock Exchanges. The results of this study became the basis of tax avoidance practices that occurred in the two countries as an implication of agency theory.
\end{abstract}

Keywords: Institutional Ownership, Tax Avoidance, Indonesia, Singapore.

\section{Introduction}

Panama papers have recently become the latest issue in showing how tax avoidance practices are carried out by individuals or business entities. In this case, it can be seen that world leaders, people who have wealth, benefit business entities store assets and invest in countries that have tax rates or even tax haven. Therefore, the practice of tax avoidance is an issue that needs to be considered by the government in making and renewing the taxation regulations that apply in a country.

Previously, a developing country needed a large amount of funds to develop both infrastructure and the welfare of its people (Akinyomi and Okpala 2013; Oktaviyani and Munandar 2017). The funds come from taxes which are compulsory contributions from individuals and business entities. The tax received will be used for development planning and meeting public needs (Aghouei and Moradi 2015; Salehi et al. 2016). The tax is cited by a special body whose duty is to collect taxes. Therefore, taxes received by the government are very beneficial for the development of a country (Aghouei and Moradi 2015; Desai and Dharmapala 2015; Irianto and Wafirli 2017).

But on the company side, tax is a burdensome expense for the company (Sari 2014). Because taxes directly impact the company's net income. For companies, taxes are expenses that are deducted from the net income after deducting operating expenses. If large taxes will have an impact on net income that will be distributed to the owner of the company. Therefore, managers look for ways to pay less taxes. This is related to the fulfillment of the interests of the company owner. 
On the other side, in the practice of implementing the company there is a conflict of interest between management and the owner. The conflict is due to differences in interests between the owner of the company as a principle and manager as an agent, namely the executor of the company. The owner of the company wants to get a return on capital through increasing the performance and value of the company so that the manager asks to improve the performance of the company (Ratnawati et al. 2018). While managers have the responsibility to run the company so that performance and value increase. Because companies that have good performance and increased value indicate that healthy companies and investors will be interested in investing in the company (Allen and Phillips 2000; Wahyudi and Pawestri 2006).

One of the managers' efforts to improve the performance and value of the company is to increase the company's net profit through the effectiveness of the expenses paid by the company so that the profits earned will increase. In addition, companies that have increased net income tend to be more stable in carrying out their operations and have an impact on the value of the company (Ratnawati et al. 2018).

But in increasing net income there are factors that influence it. One of them is tax burden. Tax expense is an obligation for the company to be paid to the state. But the lack of public trust, especially the company towards the state, causes companies to look for ways to reduce the tax paid (Akinyomi and Okpala 2013; Kanagaretnam and Lee 2013). Another factor, the increase in tax rates imposed by the company is also a heavy burden for the company (Aliani 2013). On the other hand, the desire of the owner to improve performance and value by promising compensation requires managers to look for strategies to minimize the burden and maximize net income. Therefore, the strategy carried out is tax avoidance practices (Sari 2014).

This strategy is carried out by management to plan the amount of tax that will be deposited to the state so that its value is smaller than it should be (Desai and Dharmapala 2015; Gaaya, Lakhal, and Lakhal 2017; Lanis and Richardson 2013). Previously the practice of tax avoidance was a management strategy in reducing the amount of tax liability that the company should pay to the state by utilizing existing tax regulations (Dyreng, Hanlon, and Maydew 2010; Lim 2011; Noor, Fadzillah, and Mastuki 2010; Sari 2014). Tax avoidance practices are seen from the legality divided into two, namely tax avoidance and tax evasion. Tax avoidance is a tax avoidance practice that is carried out legally by looking for weak gaps in the prevailing laws and regulations (Lim 2011). While tax evasion is a practice of tax avoidance that is carried out illegally due to finding ways to reduce the amount of tax paid by violating the existing regulations. In this study will be seen how the aspect of agency theory in tax avoidance practices.

One aspect of agency theory in tax avoidance practices is institutional ownership. Institutional ownership is the number of company sahan holders from outside the company, especially institutional, both financial and non-financial. The relationship of institutional ownership to tax avoidance practices which serves as a company supervisor so that managers in carrying out their activities are more open in delivering public information which ultimately reduces information fraud, especially tax avoidance practices as described in the Jensen and Meckling (1979) study. The size of institutional ownership affects the implementation of tax avoidance (Khurana and Moser 2009). In agency theory it is said that the principle asks agencies to improve the performance and value of the company by promising compensation to managers. The implication is that institutional ownership assigns responsibility to managers to improve company performance by supervising company operations. The goal is that managers do not violate the rules and convey the right information to the financial statements. In addition, according to (Chen et al. 2014) that tax avoidance is an act that is contrary to ethics 
and behavior that will have an impact on the decline in the value of the company (Bauer, Kourouxous, and Krenn 2018). The institutions here also consist of government institutions or legal institutions that want companies to run according to regulations. On the other side, managers know the limited resources of the company so that it is difficult to improve performance. So look for strategies to practice tax avoidance.

Research conducted by Khan, Srinivasan, and Tan (2017), Khurana and Moser (2009), Leip (2017), Ratnawati et al. (2018) Salehi et al. (2016), Sari (2014) and Ying, Wright, and Huang (2016) show that institutional ownership has a significant negative effect on tax avoidance practices. But not with research conducted by Chang, Hsiao, and Tsai (2013) Kholbadalov (2012) Masripah, Diyanty, and Fitriasari (2016) Oktaviyani and Munandar (2017) which show the opposite.

This research is to see the practice of tax avoidance carried out in two countries, namely Indonesia and Singapore. This is because the two countries are neighboring countries and have strong bilateral relations so that many investors and financial and non-financial companies invest. In addition, the two countries have different taxation systems so that the impact of these factors will be more visible that affect tax avoidance practices. So it is necessary to see the influence of institutional ownership in tax avoidance practices in Indonesia and Singapore. The results of this study can be a reference for financial and non-financial institutions in providing supervision to companies running their operations.

\section{Literature Review}

\subsection{Agency Theory and Ownership Institution}

Basically there are differences in interests between company owners and managers. As a result there is a conflict of interest that causes financial information to be conveyed asymmetrically. The owner of the company delegates its interests to the manager to achieve the desired goal while the manager wants a large compensation from the owner. Therefore, managers prepare strategies as an effort to improve the performance and value of the company,

According to Jensen and Meckling (1979) that company owners and managers have a strong bond if the manager carries out the interests of the owner of the company. But the concept of running here is that the owner promises compensation for the manager when it is reached. So that the bond between manager and owner becomes stronger if the manager runs the interests of the owner.

In this study, agency conflict occurs when the owner wants an increase in company performance and value through increasing profits with a small burden. According to Ratnawati et al. (2018) that companies that earn large profits show financial stability which has an impact on improving the performance and value of the company. So the owner orders the manager to increase the value of the company through increasing profits. One of them is with increasing load. Expenses are expenses that have an impact on the net income obtained by the company. The greater the burden on the company, the lower the net profit. According to the trade off theory, companies that have a large burden will have an impact on reducing the amount of net income earned so that a small net profit will have an impact on the taxes paid (Miller 1977). So that some companies increase debt which aims to increase interest expense which has an impact on tax reduction (Salehi et al. 2016). 
Another strategy by the company to reduce the amount of tax is by tax avoidance. Tax avoidance here is an enterprise effort to reduce the amount of tax liability paid to the government by choosing methods and recognition that have an impact on the financial statements so that the tax burden paid is reduced (Annuar, Salihu, and Obid 2014; Desai and Dharmapala 2015; Lim 2011; Palanca and Zamudio nd; Sari 2014) In terms of legality, tax avoidance is divided into two, namely legal and illegal. The tax avoidance is carried out legally by looking for loopholes in the regulations that apply to a country's tax laws. Through these weaknesses, managers formulate strategies, one of which is the use of methods or assessments that will increase the company's burden. Whereas tax evasion is illegally carried out by the company to reduce the amount of tax through the use of methods and assessments that are contrary to applicable laws. In this study, looking at tax avoidance legally by taking into account applicable regulations.

In improving the performance and value of the company to meet the interests of the owner, managers store important information by developing strategies in financial reporting. The information is useful in making decisions for company development. But tax avoidance here shows management's behavior in reporting information that does not reflect the actual conditions of the company. This is due to the lack of supervision from the owner so that managers do asymmetric information that affects the financial statements. Tax avoidance practices have a negative impact on the owner because the information conveyed in the financial statements is not in accordance with the actual conditions and the manager uses methods that have an impact on the reduction in the amount of tax. This is because, managers fulfill the interests of the manager by expecting the promised compensation so that they look for strategies to improve the company's performance. So that managers in tax avoidance must be more careful because it will affect the sanctions received (Bauer, Kourouxous, and Krenn 2018; Oktaviyani and Munandar 2017)

One of the losers is institutional ownership. This ownership is the amount of ownership from outside the company, especially the institution that holds its capital in the company. Basically, investors expect returns on capital invested as well as institutional ownership. The institution is in the form of financial and non-financial companies. Similar to individual shareholders, institutional owners also have an interest in improving the performance and value of the company so that they ask management to work seriously in achieving these goals (Salehi et al. 2016).

The existence of institutional ownership means supervision from outside parties to run the company's operations properly and in accordance with regulations (Gillan and Starks 2003; Shleifer and Vishny, W 1986). But the lack of percentage of institutional ownership causes a lack of oversight from outside parties, thus causing the possibility of tax avoidance practices in the company (Agnes Cheng et al. 2012; McGuire, Wang, and Wilson 2014). Based on Leip's (2017) research, the number of institutional ownership smaller than $40 \%$ will lead to tax avoidance practices in companies. So that it is necessary to increase institutional ownership to avoid it.

The owner of the company wants to achieve the goal, the manager must carry out its operations without harming the owner (Jensen and Meckling 1979). But the manager has information related to the company's performance so that the lack of supervision from external parties causes the manager's freedom to comply with the company's financial reporting. In accordance with agency theory, there is a conflict of interest between owners who want the company to run in accordance with the resources they have where the expectation of improved performance but managers want increased performance in the short term in the hope of large compensation from the owner. 
Research conducted by Hyun A. Hong, Ivalina Kalcheva (2017); Lim (2011); Saputra (2017) shows the results that the existence of institutional ownership makes supervision of the company's operational implementation good. This means that the higher institutional ownership causes managers to be more careful in delivering financial information and reports to the public due to tighter supervision. So that in the practice of tax avoidance, the existence of higher institutional ownership leads to a reduction in tax avoidance practices. This opinion is also supported by research conducted by Chang, Hsiao, and Tsai (2013); Leip (2017); Ratnawati et al. (2018); Salehi et al. (2016); Sari (2014); Ying, Wright, and Huang (2016). But in research conducted by Crocker and Slemrod (2005) and Slemrod (2004) shows a positive influence between institutional ownership on tax avoidance practices. on the contrary, research conducted by Chang, Hsiao, and Tsai (2013; Kholbadalov (2012); Masripah, Diyanty, and Fitriasari (2016); Oktaviyani and Munandar (2017) shows the results that institutional ownership does not affect managers in tax avoidance practices. these two opinions have not been obtained by empirical evidence of the existence of institutional ownership in the company against the practice of tax avoidance as a theoretical evidence of agency theory on the company.

In this study comparing between two countries, namely Indonesia and Singapore, which aims to look at the two countries of the state how the practice of tax avoidance is based on agency conflict. Every country has different tax regulations so that empirical evidence will be obtained about the practice. In addition, this study also looks at the characteristics of individual investors so that the results of this study provide information to the public about the characteristics of investors and tax avoidance practices between the two countries, namely Indonesia and Singapore.

\section{Methodology}

\subsection{Research Sample}

This research was conducted between two countries, namely Indonesia and Singapore. The type of company used is a manufacturing company listing 2015-2016. The type of data used is secondary data derived from the sample company's financial statements. Data is obtained from the Indonesia Stock Exchange and Singapore Stock Exchange.

\subsection{Research Model}

The model of this research is simple linear regression. The results of this model will be obtained information on the effect of institutional ownership on tax avoidance practices as evidence of agency theory by company owners and managers. The models in this study are as follows:

$$
\text { TAit }=\alpha+\beta 1 \times 1+\varepsilon
$$

The TAit is a tax avoidance practice as measured by ETR which is calculated by comparing the tax burden with the amount of net income before tax obtained by the company (Dyreng, Hanlon, and Maydew 2010; Lanis and Richardson 2013; Oktaviyani and Munandar 2017; Sari 2014). The value of tax avoidance is $25 \%$, indicating that the smaller the company practices tax avoidance (Oktaviyani and Munandar 2017). While institutional ownership is measured by comparing the number of institutional ownership with the number of shareholdings contained in the company (see research by Saputra (2017); Thai Ha and Quyen 
(2017). So that is obtained the knowledge whether the greater institutional share ownership has an impact on reducing tax avoidance practices.

\section{$4 \quad$ Results and Discussion}

\subsection{Descriptive Statistics}

The following are descriptive statistical results of institutional ownership in companies on the Indonesia Stock Exchange and the Singapore Stock Exchange.

Table 1 Descriptive Statistics of Institutional Ownership in Indonesia

\begin{tabular}{lcccc}
\hline & $\mathrm{N}$ & Minimum & Maximum & Mean \\
\hline $\begin{array}{l}\text { Institutional } \\
\text { Ownership }\end{array}$ & 180 & 0.14 & 0.99 & 0.6659 \\
\hline
\end{tabular}

Based on table 1, the results show that the number of institutional ownership in Indonesia is greater than $40 \%$. So that indicates the high participation of institutional ownership in overseeing company activities. So that the avoidance of conflicts of interest between the principal and the agent and avoiding the practice of tax avoidance.

Table 2 Descriptive Statistics of Institutional Ownership in Singapore

\begin{tabular}{lcccc}
\hline & $\mathrm{N}$ & Minimum & Maximum & Mean \\
\hline $\begin{array}{l}\text { Institutional } \\
\begin{array}{l}\text { Ownership > 40\% } \\
\text { Institutional }\end{array}\end{array}$ & 22 & 0.40 & 0.98 & 0.7006 \\
Ownership <40\% & 42 & 0.01 & 0.39 & 0.1998 \\
\hline
\end{tabular}

Based on table 2 above it can be seen that the average company listing on the Singapore Stock Exchange has more than $40 \%$ ownership which indicates that the supervision of external parties is high in the course of the company's operational activities. This result also indicates a smaller conflict of interest due to strict supervision of the implementation of company activities.

\subsection{Results}

The research model was tested using simple linear regression. Here are the results of testing the model using linear regression on companies listing on the Indonesia Stock Exchange.

Table 3 Hypothesis Testing in Indonesia

\begin{tabular}{|c|c|c|c|c|c|}
\hline & \multirow[t]{2}{*}{ Model } & \multicolumn{2}{|c|}{$\begin{array}{l}\text { Unstandardized } \\
\text { Coefficients }\end{array}$} & \multirow[t]{2}{*}{$\mathrm{T}$} & \multirow[t]{2}{*}{ Sig. } \\
\hline & & $\mathrm{B}$ & Std. Error & & \\
\hline \multirow[b]{2}{*}{1} & (Constant) & -1.458 & 0.131 & -11.147 & 0.000 \\
\hline & $\begin{array}{l}\text { Institutional } \\
\text { Ownership }\end{array}$ & 0.207 & 0.189 & 1.094 & 0.275 \\
\hline
\end{tabular}

Based on table 3 above it can be seen that institutional ownership does not affect the practice of tax avoidance both large companies and small companies. Besides that, the research model is obtained as follows: 


$$
\mathrm{Y}=-1,458+0.207 \mathrm{X} 1
$$

The following are the results of testing the research model on companies listing on the Singapore Stock Exchange. In testing the hypothesis is divided into 2 parts, namely the ownership of institutions less than $40 \%$ and more than $40 \%$ as said in the research of Khan, Srinivasan, and Tan (2017). The following are the test results in Tables 2 and 3.

Table 4 Hypothesis Testing with Ownership $<40 \%$

\begin{tabular}{|c|c|c|c|c|c|c|}
\hline \multirow{2}{*}{\multicolumn{2}{|c|}{ Model }} & \multicolumn{2}{|c|}{ Unstandardized Coefficients } & & \multirow{2}{*}{\multicolumn{2}{|c|}{ Sig. }} \\
\hline & & $\mathrm{B}$ & Std. Error & $\mathrm{t}$ & & \\
\hline & (Constant) & -1.638 & 0.286 & & -5.719 & 0.000 \\
\hline & Institutional Ownership & -0.367 & 1.256 & & -0.293 & 0.771 \\
\hline \multicolumn{7}{|c|}{ a. Dependent Variable: Tax Avoidance } \\
\hline
\end{tabular}

Based on Table 4 above, the results show that institutional ownership does not have a significant effect on tax avoidance practices, although the percentage of ownership is less than $40 \%$ which indicates weakness in company supervision. The research model is:

$$
\mathrm{Y}=-1.638-0.367 \mathrm{X} 1
$$

The following in table 5 looks at model testing if ownership is greater than $40 \%$.

\begin{tabular}{|c|c|c|c|c|}
\hline \multirow[t]{2}{*}{ Model } & \multicolumn{2}{|c|}{ Unstandardized Coefficients } & \multirow[b]{2}{*}{$\mathrm{t}$} & \multirow[b]{2}{*}{ Sig. } \\
\hline & B & Std. Error & & \\
\hline \multirow{3}{*}{ Institutional Ownership } & -1.801 & 0.333 & -5.415 & 0.000 \\
\hline & 0.208 & 0.464 & 0.449 & 0.654 \\
\hline & & & & \\
\hline
\end{tabular}

Table 5 Hypothesis Testing with Ownership> 40\%

Based on table 5 above, the results show that institutional ownership does not have a significant effect on tax avoidance practices even though ownership is greater than $40 \%$. The model for ownership testing greater than $40 \%$ is:

$$
\mathrm{Y}=-1,801+0.208 \mathrm{X} 1
$$

\section{Discussion}

Based on the results of testing the linear regression analysis obtained the results that the existence of institutional ownership in a company in general does not affect managers in tax avoidance practices. This result is contrary to what was previously stated in agency theory. In agency theory, managers make tax planning that aims to reduce the amount of tax paid to the state legally. The aim is that the profits earned by the company are not too large to be paid to the state in the form of tax expense.

In addition, according to the agency theory that profits derived from tax avoidance are used for returns to owners and bonuses to managers. But on the contrary the results of this study indicate there is no influence both large and small institutional ownership contained in the company. Contrary to the opinion of Khurana and Moser (2009) that the percentage of institutional ownership in a company greatly influences the practice of tax avoidance by a company. This is due to institutional ownership as an internal supervisor in carrying out the company's operational activities. This is supported by Salehi et al. (2016) that institutional 
ownership functions as a supervisor so as to minimize the practice of tax avoidance. This result is in line with research conducted by Kholbadalov (2012); Khurana and Moser (2009); Masripah, Diyanty, and Fitriasari (2016); Sari (2014) where the results of this study indicate that there is no influence between institutional ownership on tax avoidance practices.

The results of this study indicate that institutional ownership does not always function as a supervisor in a company or that there are other interests of institutional ownership in taking ownership of a company such as to be easy to monitor in terms of profit sharing, supervision of debt payments, and others (Kholbadalov 2012). Based on the results also shows that managers have other interests in improving the performance and value of the company which aims to attract the attention of investors in investing in the company. With the increasing performance, investors are expected to have a positive outlook on the company.

In addition, this study was conducted in two countries, namely Indonesia and Singapore, which indicated that both share ownership in Indonesia and Singapore paid little attention to supervision of tax avoidance practices in both Indonesia and Singapore where institutional ownership generally did not affect tax avoidance practices. If we look like in companies in Indonesia, the amount of institutional ownership exceeds $50 \%$ which is seen in the average share ownership where supervision of the company is very large but does not have an impact on tax avoidance practices. So that there are other interests such as in overseeing investment decision making, supervision of dividends, supervision of payment obligations, and others. So this result also contradicts the research conducted by Khan, Srinivasan, and Tan (2017); Leip (2017); Ratnawati et al. (2018); Salehi et al. (2016); Ying, Wright, and Huang (2016) where institutional ownership has a negative effect on tax avoidance practices. The results of this study indicate that there is evidence of the practice of agency theory where institutional ownership supervises managers who have different interests with company owners.

\section{CONCLUSION}

Based on the results of the research model, it was concluded that the number of institutional ownership in both Indonesia and Singapore did not have a significant influence on tax avoidance practices as evidenced in the research conducted by Khan, Srinivasan, and Tan (2017); Khurana and Moser (2009); Leip (2017); Ratnawati et al. (2018); Salehi et al. (2016); Sari (2014); Ying, Wright, and Huang (2016). These results indicate that institutional ownership has other interests such as dividend payments, supervision of debt payments, and others. In addition, managers improve the performance and value of the company aims to attract the attention of investors in investing their capital in the company so that it becomes an additional capital that can be used to develop the company. The results of this study are in line with research conducted by L. L. Chang, Hsiao, and Tsai (2013); Kholbadalov (2012); Masripah, Diyanty, and Fitriasari (2016); Oktaviyani and Munandar (2017). 


\section{References}

[1] Aghouei, M. V., \& Moradi, M. (2015). A Study of the Relationship of Firm Characteristics and Corporate Governance with the Difference between Declared and Final Taxes in Iran. Mediterranean Journal of Social Sciences, 6(4), 488-498.

[2] Agnes Cheng, C. S., Huang, H. H., Li, Y., \& Stanfield, J. (2012). The effect of hedge fund activism on corporate tax avoidance. Accounting Review, 87(5), 1493-1526.

[3] Akinyomi, O. J., \& Okpala, K. (2013). Appraisal of factors influencing tax avoidance and evasion in Nigeria. International Journal of Research in Commerce \& Management, 4(5), $107-$ 111.

[4] Aliani, K. (2013). Does Corporate Governance affect tax planning? Evidence from American companies. International Journal of Advanced Research, 1(10), 864-873.

[5] Allen, J. W., \& Phillips, G. M. (2000). Corporate equity ownership, strategic alliances, and product market relationships. Journal of Finance, 55(6), 2791-2815.

[6] Annuar, H. A., Salihu, I. A., \& Obid, S. N. S. (2014). Corporate Ownership, Governance and Tax Avoidance: An Interactive Effects. Procedia - Social and Behavioral Sciences, 164(October 2016), 150-160.

[7] Bauer, T., Kourouxous, T., \& Krenn, P. (2018). Taxation and agency conflicts between firm owners and managers: a review. Business Research, 11(1), 33-76.

[8] Chang, L.-L., Hsiao, F. D., \& Tsai, Y.-C. (2013). Earnings, institutional investors, tax avoidance, and firm value: Evidence from Taiwan. Journal of International Accounting, Auditing and Taxation, 22(2), 98-108.

[9] Chang, L. L., Hsiao, F. D., \& Tsai, Y. C. (2013). Earnings, institutional investors, tax avoidance, and firm value: Evidence from Taiwan. Journal of International Accounting, Auditing and Taxation, 22(2), 98-108.

[10] Chen, X., Hu, N., Wang, X., \& Tang, X. (2014). Tax avoidance and firm value: evidence from China. Nankai Business Review International, 5(1), 25-42.

[11] Crocker, K. J., \& Slemrod, J. (2005). Corporate tax evasion with agency costs. Journal of Public Economics, 89(9-10), 1593-1610.

[12] Desai, M. A., \& Dharmapala, D. (2015). Corporate tax avoidance and firm value (689 cit). The Review of Economics and Statistics, 91(3), 537-546.

[13] Dyreng, S. D., Hanlon, M., \& Maydew, E. L. (2010). The effects of executives on corporate tax avoidance. Accounting Review, 85(4), 1163-1189.

[14] Gaaya, S., Lakhal, N., \& Lakhal, F. (2017). Does family ownership reduce corporate tax avoidance? The moderating effect of audit quality. Managerial Auditing Journal, 32(7), 731-744.

[15] Gillan, S., \& Starks, L. T. (2003). Corporate Governance, Corporate Ownership, and the Role of Institutional Investors: A Global Perspective. Journal of Applied Finance, 13(2), 4-22.

[16] Hong, H. A., Kalcheva, I., \& Srivastava, A. (2017). A reexamination of the theory of agency costs of tax avoidance Hyun A. Hong, Ivalina Kalcheva, Anup Srivastava * January 15, 2017. EMMA, 1-43.

[17] Irianto, B. S., \& Wafirli, A. (2017). The Influence of Profitability, Leverage, Firm Size and Capital Intensity Towards Tax Avoidance. International Journal of Accounting and Taxation, $5(2), 33-41$.

[18] Jensen, M. C., \& Meckling, W. H. (1979). Theory of the Firm: Managerial Behavior, Agency Costs, and Ownership Structure. Journal of Financial Economics, 3(4), 163-231.

[19] Kanagaretnam, K., \& Lee, J. (2013). Societal Trust and Corporate Tax Avoidance $\square$. Research Collection School Of Accountancy, (December).

[20] Khan, M., Srinivasan, S., \& Tan, L. (2017a). Institutional Ownership and Corporate Tax Avoidance: New Evidence. The Accounting Review, 92(2), 101-122.

[21] Khan, M., Srinivasan, S., \& Tan, L. (2017b). Institutional Ownership and Corporate Tax Avoidance: New Evidence. The Accounting Review, 92(2), 101-122.

[22] Kholbadalov, U. (2012a). The relationship of corporate tax avoidance, cost of debt and institutional ownership: evidence from Malaysia. Atlantic Review of Economics, 2675377(2). 
[23] Kholbadalov, U. (2012b). The relationship of corporate tax avoidance, cost of debt and institutional ownership: evidence from Malaysia. Atlantic Review of Economics, 2.

[24] Khurana, I. K., \& Moser, W. J. (2009). Institutional Ownership and Tax Aggressiveness. Financial Accounting and Reporting Section (FARS) Paper, (573), 0-42.

[25] Lanis, R., \& Richardson, G. (2013). Corporate social responsibility and tax aggressiveness: A test of legitimacy theory. Accounting, Auditing and Accountability Journal, 26(1), 75-100.

[26] Leip, T. A. (2017). Do institutional shareholders impact corporate tax avoidance? Master's Thesis Annika Leipälä Spring 2017 AccountingAnnika Leipälä Spring 2017 Accounting.

[27] Lim, Y. (2011). Tax avoidance, cost of debt and shareholder activism: Evidence from Korea. Journal of Banking and Finance, 35(2), 456-470.

[28] Masripah, Diyanty, V., \& Fitriasari, D. (2016). Controlling Shareholder and Tax Avoidance: Family Ownership and Corporate Governance. International Research Journal of Business Studies, 8(3), 167-180.

[29] McGuire, S. T., Wang, D., \& Wilson, R. J. (2014). Dual class ownership and tax avoidance. Accounting Review, 89(4), 1487-1516.

[30] Miller, M. H. (1977). Debt and Taxes. The Journal of Finance, XXXII(2), 637-657.

[31] Noor, R. M., Fadzillah, N. S. M., \& Mastuki, N. (2010). Corporate Tax Planning: A Study On Corporate Effective Tax Rates of Malaysian Listed Companies. International Journal of Trade, Economics and Finance, 1(2), 189-193.

[32] Oktaviyani, R., \& Munandar, A. (2017). Effect of Solvency, Sales Growth, and Institutional Ownership on Tax Avoidance with Profitability as Moderating Variables in Indonesian Property and Real Estate Companies. Binus Business Review, 8(3), 183.

[33] Palanca, T. J. R., \& Zamudio, I. G. C. (n.d.). an Analysis of the Agency Perspective on Tax Avoidance and Firm Value Under Different Corporate Governance Structures : the. Presented at the Research Congress 2013, De La Salle University Manila, (2003), 1-9.

[34] Ratnawati, V., Azhari, S., Freddy, D., \& Wahyuni, N. (2018). The Impact of Institutional Ownership and a Firm's Size on F irm Value: Tax Avoidance as a Moderating Variable. Journal of Finance and Banking Review, 3(1), 1-8.

[35] Salehi, A. K., Baharipour, A., Mohammadi, S., Branch, M., Branch, K. G. I., \& Ownership, I. (2016). The Impact of Institutional Ownership on The Relationship between Tax and Capital Structure. Advances in Mathematical Finance \& Applications, 1(2), 57-67.

[36] Saputra, M. (2017). The Influence of Ownership Structures , Financial Distress , and Tax Loss Carry Forward on Tax Avoidance. Journal of Resources Development and Management, 31(2011), 21-31.

[37] Sari, G. M. (2014). Pengaruh Corporate Governance, Ukuran Perusahaan, Kompensasi Rugi Fiskal Dan Struktur Kepemilikan Terhadap Tax Avoidance. Jurnal WRA, 2(2), 1-25.

[38] Shleifer, A., \& Vishny, W, R. (1986). Large Shareholders and Corporate Control. Journal of Political Economy, 94(3), 461-488.

[39] Slemrod, J. (2004). The Economics of Corporate Tax Selfishness. National Tax Journal, LVII(4), 877-899.

[40] Thai Ha, N. T., \& Quyen, P. G. (2017). The relationship between state ownership and tax avoidance level: empirical evidence from Vietnamese firms. Journal of Asian Business Strategy, $7(1), 1-12$.

[41] Wahyudi, U., \& Pawestri, H. P. (2006). Implikasi Struktur Kepemilikan Terhadap Nilai Perusahaan: Dengan Keputusan Keuangan Sebagai Variabel Intervening. Simposium Nasional Akuntansi 9 Padang, 53, 160.

[42] Ying, T., Wright, B., \& Huang, W. (2016). Ownership Structure and Tax Aggressiveness of Chinese Listed Companies. International Journal of Accounting \& Information Management, 25(3) 